European

Policy

Research

Unit

Series

$$
\text { Fifteen }
$$

into one?

The European

Union and its

member states

Edited by

Wolfgang Wessels,

Andreas Maurer

\& Jürgen Mittag 


\section{Fifteen into one?}

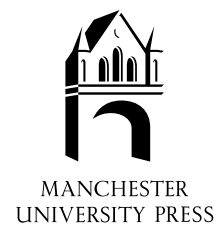


European Policy Research Unit Series

Series Editors: Simon Bulmer, Peter Humphreys and Mick Moran

The European Policy Research Unit Series aims to provide advanced textbooks and thematic studies of key public policy issues in Europe. They concentrate, in particular, on comparing patterns of national policy content, but pay due attention to the European Union dimension. The thematic studies are guided by the character of the policy issue under examination.

The European Policy Research Unit (EPRU) was set up in 1989 within the University of Manchester's Department of Government to promote research on European politics and public policy. The series is part of EPRU's effort to facilitate intellectual exchange and substantive debate on the key policy issues confronting the European states and the European Union.

Titles in the series also include:

The governance of the Single European Market Kenneth Armstrong and Simon Bulmer

The politics of health in Europe Richard Freeman

Immigration and European integration Andrew Geddes

Mass media and media policy in Western Europe Peter Humphreys

The regions and the new Europe Martin Rhodes (ed.)

The rules of integration Gerald Schneider and Mark Aspinwall

Political economy of financial integration in Europe Jonathan Story and Ingo Walter

Extending European cooperation Alasdair R. Young

Regulatory politics in the enlarging European Union Alasdair Young and Helen Wallace 


\section{Fifteen}

into one?

\section{The European Union and its member states}

Edited by

Wolfgang Wessels, Andreas Maurer and Jürgen Mittag

Manchester University Press Manchester and New York

distributed exclusively in the USA by Palgrave 
While copyright in the volume as a whole is vested in Manchester University Press, copyright in individual chapters belongs to their respective authors, and no chapter may be reproduced wholly or in part without the express permission in writing of both author and publisher.

Published by Manchester University Press Oxford Road, Manchester M13 9NR, UK

and Room 400, 175 Fifth Avenue, New York, NY 10010, USA

www.manchesteruniversitypress.co.uk

Distributed exclusively in the USA by Palgrave, 175 Fifth Avenue, New York, NY 10010, USA

Distributed exclusively in Canada by

UBC Press, University of British Columbia, 2029 West Mall, Vancouver, BC, Canada V6T 1Z2

British Library Cataloguing-in-Publication Data

A catalogue record for this book is available from the British Library

Library of Congress Cataloging-in-Publication Data applied for

ISBN 071905849 X paperback

First published 2003

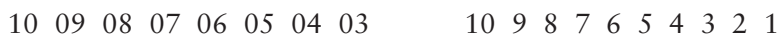

Typeset in Sabon

by Action Publishing Technology Ltd, Gloucester

Printed in Great Britain

by Bookcraft (Bath) Ltd, Midsomer Norton 